\title{
Negotiating identity: reburial and commemoration of the civil war dead in southwestern Spain
}

Zahira Araguete-Toribio Goldsmiths University London

zahira.araguete@googlemail.com

\begin{abstract}
This article considers how the reburial and commemoration of the human remains of the Republican defeated during the Spanish Civil War (1936-39) is affected by the social, scientific and political context in which the exhumations occur. Focusing on a particular case in the southwestern region of Extremadura, it considers how civil society groups administer reburial acts when a positive identification through DNA typing cannot be attained. In so doing, the article examines how disparate desires and memories come together in collective reburial of partially individuated human remains.
\end{abstract}

Key words: DNA typing, reburial, Spanish Civil War, exhumations, local commemoration, collective memory

In the last decade, the unearthing of war and post-war mass graves containing the bodies of the Republican defeated during the Spanish Civil War (1936-39) has reunited the human remains of killed and missing relatives with living families and communities at large. After more than seventy years lying in furtive internments outside of their localities or in graves elsewhere, their recovery has prompted the return of these bodies to the cemeteries of the villages and towns where they once lived, to be reburied and commemorated locally. In some cases, bodies have been successfully identified and given burial in family tombs. In others, they have been buried collectively, especially when the remains of some cannot be identified. In Spain, the reburial and commemoration of these human remains, as in other cases, is acutely entrenched with the predicaments of their forensic identification and analysis. ${ }^{1}$ Most importantly, however, they are also enmeshed with the political controversies that surround exhumations. On the one hand, the lack of information about the deceased in archives and other ante-mortem records and, especially, the impossibility of finding many living relatives have in many cases made a positive identification through DNA testing highly taxing. On the other, identification and reburial processes have been marked by quandaries around the remembrance of the war's deceased at national and local levels.

The lack of commitment from the central government and judiciary to investigate 
Francoist crimes and to exhume and commemorate these human remains has generated complex relationships between families, activists and the Spanish State over the years. Historical literature on the commemoration of death post-conflict has long examined the connection between dead bodies, their burial and the remembrance and politics of national identity. ${ }^{2}$ Some of these studies - which focus on forms of memorialisation, especially after World War One - have shown the way in which states manage the familial and collective commemoration of the war dead in an effort to reassert the nation's symbolic unity and communal sentiment. Most recently, the advance of new techno-scientific means for the identification and individuation of human remains in the aftermath of war and disaster have prompted a new way of accounting for mass death, shaping, as Sarah Wagner has diversely demonstrated, the meanings of national commemoration. ${ }^{3}$ A close look at the particular way in which these practices are carried out in different contexts elucidates how human remains and their scientific conception are produced vis-àvis states' ethnic, religious and political aspirations. ${ }^{4}$ In Spain, where civil society groups - formed by members of second, third and fourth generations - have administered the exhumation, identification and reburial of exhumed human remains from the war and post-war periods have seen a 'decentralisation' of commemoration and remembrance practices to the margins of statist action. ${ }^{5}$ Since the year 2000, the work of families, activists and, on occasions, local town halls and regional institutions have produced new spaces of worship and ritual for these Republican dead.

In Extremadura, where I carried out fieldwork between 2011 and 2012, family groups and associations often decided to bury exhumed human remains collectively, as the poor conservation of bones or the absence of relatives hampered their positive identification. In these reburials, unidentified remains were individuated, scientifically labelled and placed together inside a mausoleum. During the public act of reburial, the names of the victims were recalled and their personal histories reclaimed. In the process, however, different needs often converged when negotiating the fate of the Republican dead and their commemoration. Focusing on the intersections between scientific identification and memorialisation, this article explores the particularities of reburial work in the Spanish context. The article first broadly examines the role of DNA testing in the analysis of human remains from Spanish mass graves. Secondly, through the discussion of a particular case in Extremadura, the article analyses how common burials are subject to particular scientific, familial and political exigencies, becoming, at times, sites of struggle. ${ }^{6}$ Lastly, it considers how such novel funerary celebrations and inscriptions constitute other forms of re-associating and identifying the deceased socially, especially when a DNA match cannot be attained. ${ }^{7}$

\section{Identification and reburial practices in twenty-first century Spain}

As in other recent post-conflict scenarios, the act of reburying the bodies found in war and post-war mass graves in Spain is preceded by the archaeological excavation of the human remains, the individuation of each corpse, the anthropological 
study of the bones - of their ante-mortem, perimortem and post-mortem traits and later their DNA typing. DNA technology has reconvened families with their disappeared relatives and become a political agent in the mediation of complex identification demands in the aftermath of mass atrocity. ${ }^{8}$ As Sarah Wagner has discussed, the search for genetic identification and return of human remains to families have united scientific practice and social expectations in the restoration of disrupted kinship relations. ${ }^{9}$ It has also further entangled the lives of survivors with the aspirations of the State. In particular instances such as the Srebrenica genocide, authors such as Wagner have addressed how DNA testing has become a key technology that 'speaks to the state's capacities to regulate and respond to the need of its citizens. ${ }^{10}$ In her analysis, however, Wagner is critical of how such DNA technologies are used to reassert states' authority in a landscape of different political claims and to obscure previous forms of governmental inaction or disdain in situations of emergency. Indeed, this 'technology of repair', as Wagner calls it, turns sovereign power into an authority that allegedly cares while concealing past negligence, especially in the aftermath of extreme violence - political, ethnic, religious or otherwise. ${ }^{11}$

In Spain, independent scientific teams have guided the individuation of the corpses found in mass graves from the civil war and the post-war period since the beginning of the exhumation movement at the turn of the twenty-first century. Contrary to the Bosnian case, for instance, the positive identification of these human remains has never been a matter of state priority and, alongside other activities such as exhumations, has been made a responsibility of civil society groups.

The progressive endorsement of historical memory-related projects by the State in the years when the Socialist Party (Partido Socialista Obrero Español; PSOE henceforth) governed the country from 2004 until 2011 showed, for some, a level of official engagement. Nonetheless, many still regard the restorative legislation enforced in 2007 - commonly known as the Law of Historical Memory ${ }^{12}$ - as insufficient, as it legally 'outsources' all exhumation, identification and reburial work to families and associations. ${ }^{13}$ Over the years, many activists in the country have widely critiqued the role of the State as a bystander, which proposed new measures for the legal and moral acknowledgement of the victims, the subsidy of exhumations and identifications or the regulation and standardisation of excavation practices, but who never implemented these rulings first-hand. The arrival of the conservative Popular Party (Partido Popular; PP henceforth) government left scientists and civil society groups feeling more helpless. A look at the website of the Spanish Ministry of Justice and its section on 'Historical Memory' today suffices one to appreciate the paralysation of most funding connected to exhumations and body identifications since $2011 .^{14}$

DNA testing has, however, played an important role in the identification of some human remains found in Spanish mass graves, especially since 2006, when the Ministry of the Presidency - in accordance to the Law of Historical Memory - provided financial help for their individuation. ${ }^{15}$ As Francisco Ferrándiz has argued, this transformed the expectations of many relatives, who then envisaged the recuperation of 'concrete cadavers' - moving away from the consequent 
practices of communal burial that predominated in the first years of the exhumations. ${ }^{16}$ DNA typing has only been performed, however, in cases where conditions were most favourable.

Due to the temporal divide between the killings and the exhumation, forensic scientists working on war and post-war mass graves in Spain have advised that DNA testing cannot be taken in isolation. Instead, they caution, it needs to be 'targeted' or related to other types of presumptive and osteological identification attained through the cross-referencing of archival sources, testimonies and the osteological study of bones and dentures. ${ }^{17}$ Rios et al. have further highlighted that identification processes in Spain depend on numerous factors. ${ }^{18}$ Elements such as the number of bodies found in the mass grave, their preservation and related belongings, the methods available for their analysis and the 'quantity and quality' of ante-mortem data, and 'the availability of financial support and living relatives' for DNA analysis are key to securing a positive identification. ${ }^{19}$

Berta Silva, a member of the excavation team from the Universidad Autónoma de Madrid led by biologist Luis Rios, explains that the cases they have dealt with, principally in exhumations in northern Spain, have allowed her team to complete a DNA analysis of human remains regularly since 2006. In fact, as she observed, individual identification through DNA is performed every time it is possible and not only when it is demanded by families because it is 'part of their working procedure'. ${ }^{20}$ Indeed, for many living relatives, recovering their ancestors' remains fulfilled a life-long wish to return them to the solemn ground of the cemetery, where other members of the family rest. As Berta further described, many families claim these remains to inter them in private familial gravesites. Nonetheless, the archaeologist explained that in all cases she had worked a common mausoleum was usually built to accommodate identified, partially identified and unknown human remains - identifications made through presumptive and anthropological examination. Corpses, especially those whose families could not be located, would be buried here in individual coffins with the relevant scientific information on their human traits, ready for future exhumation and identification.

For instance, in cases such as the excavation of the Central Prison of Valdenoceda in Burgos where a vast number of bodies were exhumed and analysed, the families' association took responsibility for the burial and commemoration of the human remains that could not be returned to their families. ${ }^{21}$ The identification of some of these corpses was concluded on the basis of clear presumptive and osteological data found in archival sources and in anthropological studies respectively. Volunteers from the association still today continue, however, searching for relatives in order to secure the DNA typing of corpses in order to achieve a final positive identification, as the blog dedicated to the exhumation describes. ${ }^{22}$ Time has dispersed numerous families and made the reencounter with the remains of their relatives arduous. In different instances, time has also complicated the extraction of information from files (sometimes damaged or destroyed) and from the human remains in mass graves (on occasions, deteriorated by the physical environment in which they are kept). These contingencies are also contemplated as a part of the exhumations' protocol issued on 27 September 2011, which further connects ques- 
tions about the identification of the civil war and post-war dead to their final fate and resting place. As part $\mathrm{E}$ of the last section of the protocol advises:

E) Final Resting Place of Human Remains

Once human remains are studied and identified, depending on whether they have been identified or not, their burial will proceed as follows:

1. Identified [human remains]: families will receive them and perform the ceremony they consider appropriate.

2. Not identified: [human remains] will be inhumed at the cemetery of the location where the mass grave is located. The most adequate containers will be used, according to the recommendations of conservation and restoration experts. Each body will be buried individually, together with their personal belongings, with an identification that allows their location in future exhumations. This identification should include in all cases their case-study number.

Likewise, authorisation from the Autonomous Community or relevant Local Entity will be required for the transportation of human remains as well as for their re-inhumation or cremation. ${ }^{23}$

Many experts consider the protocol, issued at the end of the PSOE mandate, a much-delayed set of guidelines, which followed years of practice connected, in some cases, to the 'heterogeneous and uneven protocols' produced by regional authorities. ${ }^{24}$ Indeed, the document's recommended procedures are shaped by international methods and the experience of Spanish teams over time. ${ }^{25}$ Its content then reflects some particularities of the Spanish case. As the fragment above suggests, aspects connected to the re-inhumation of war and post-war cadavers in the country are, for instance, largely influenced by the precepts of their identification as well as the legal and political context of the place where they are interred. ${ }^{26}$ Authors such as Wagner have observed that the complexities encountered in some processes of identification - for instance in reference to her study of commingled remains in Bosnian secondary mass graves - have, in fact, generated the creation of innovative burial practices and forms to cater for the dead and its social mourning. ${ }^{27}$ This was certainly the case in the region of Extremadura, where some exhumations exposed human remains which, extremely affected by the acidity of the soil, had effectively turned into dust. Following the trajectory of these corpses from the mass grave to the reburial site revealed, in some cases, how family members coped with the impossibility of a positive identification and, as Wagner observed in Bosnia, how they actively conceived and realised the re-internment of their dead ancestors in the village cemetery.

\section{Identification and collective reburial in Extremadura}

As in other parts of the country, teams in Extremadura experienced difficulties when trying to accomplish the positive identification of human remains in mass graves. This is not to say that DNA typing has not been done at all or that a positive identification of exhumed remains has never been accomplished in the region. 


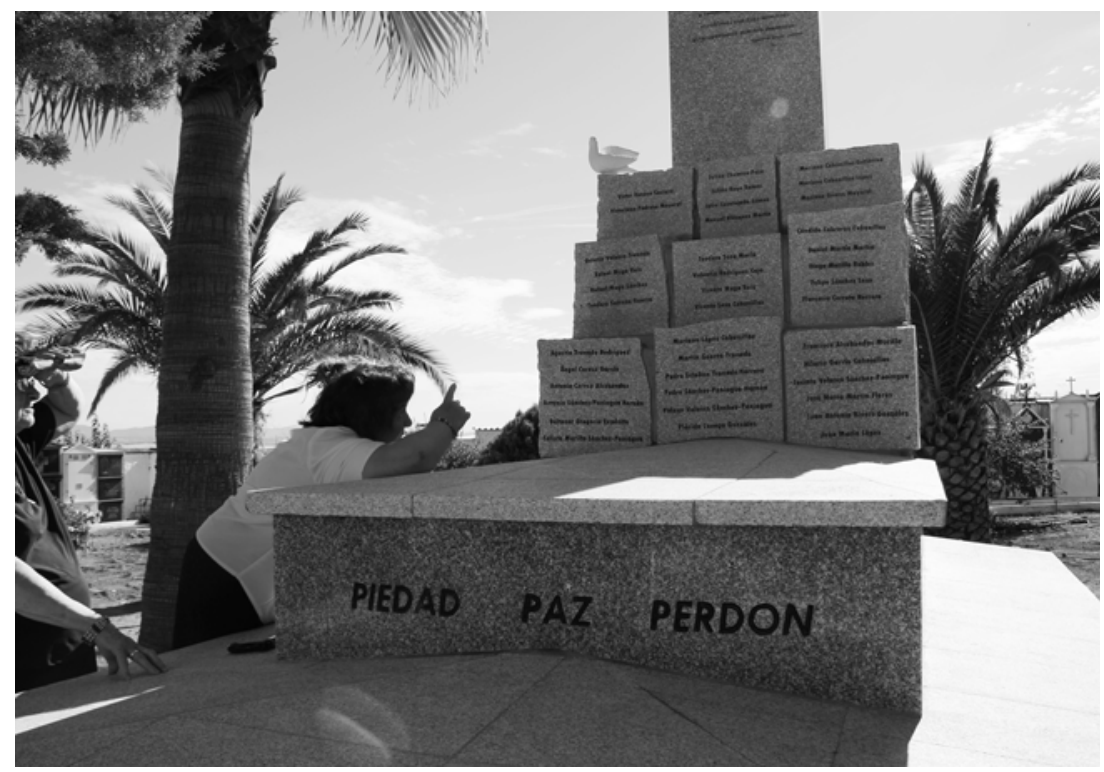

Figure 1 Mausoleum in the cemetery of Puebla de Alcocer where the 42 bodies exhumed rest. The names of those killed at the mass grave are listed on the top and the inscription at bottom reads: 'Compassion, Peace, Forgiveness'

As Laura Muñoz, the archaeologist and physical anthropologist with whom I worked (part of the Project for the Recovery of Historical Memory in Extremadura; PREMHEx, in its Spanish acronym) explained to me, some excavations such as the one carried out in the village of Villasbuenas de Gata, north of Extremadura, in 2009 resulted in the successful exhumation, analysis and genetic match of the remains unearthed. The archaeologist - who worked for over eight years in the research project convened by the University of Extremadura, the Culture Regional Ministry and the Councils of the two provinces in the region, Cáceres and Badajoz $^{28}$ - noted, however, that DNA analysis becomes especially difficult in the case of mass graves containing numerous corpses.

In 2012, I participated as part of Laura Muñoz's team in the exhumation of the bodies of forty-two men buried in two war trenches outside the village of Puebla de Alcocer (southern Extremadura). The excavated human remains presented disparate complications that made positive but also presumptive and osteological identification gruelling. In Puebla, identification work was greatly affected by the limited number of living relatives located - many families had migrated elsewhere after the war - and the few and unreliable records found on extrajudicial executions in the civil registry, where only death certificates with ambiguous descriptions of the men's deaths remained. According to the testimonies gathered, the corpses of these men, executed by right-wing neighbours with the help of Francoist troops and scattered along six mass graves, remained exposed after their killings. Later on, the 
widows of some of the deceased managed to secretly reach the site to bury them, covering them lightly with soil. As these stories recounted, and later scientific practice attested, carnivores and vermin soon comingled and displaced their body parts. This made anatomic connection difficult to discern at the time of the excavation. In addition to this, the degeneration of some corpses in post-depositional processes further impeded bone association and the sight of their shattered materiality conjured for close kin the futility of their identification. Throughout the exhumation, the archaeologist also made families aware of the difficulty scientists would face when matching human remains with the names of the prisoners allegedly executed on the 21 and 25 May 1939 - according to the inscriptions on their death certificates.

From the beginning, however, and in the light of other difficulties observed prior to the exhumation campaign, the reburial of the human remains found in Puebla de Alcocer was conceived as a collective act. After liaising with the archaeologist, for instance, José Sánchez-Paniagua, the grandson of one of the men in the grave who promoted the search and exhumation, considered that the challenging effort to locate all families related to the men could turn the analysis and profiling of human remains into an everlasting process. Moreover, he also observed that this difficulty existed when families were found, as some did not 'want to know anything about the mass graves or their relatives'. ${ }^{29}$ José spent over six years researching his grandfather's execution and gathering details about the lives and deaths of all those who perished with him. Having only located half of the families of the forty-two men in the mass grave meant that many corpses would remain unnamed even if a DNA test could be secured. José acknowledged that, in the event of a DNA test, he might obtain the remains of his grandfather and his granduncle - also in the mass grave - but wondered what would happen to the remaining unidentified corpses of the other neighbours from Puebla. Though financial aid from the Ministry of the Presidency covered the exhumation, scant funds for DNA analysis made the individuation of this large number of corpses highly unlikely. Looking for families and funding would mean, in the view of many like José, the delay of a much-desired end: to bury the bodies at the village's cemetery. The sense of urgency to fulfil this awaited moment, especially as many relatives from older generations were quickly passing away, propelled the decision of a collective reburial.

For José a collective burial in a mausoleum, like the one on Figure 1, was a fair option as all the deceased could rest and be commemorated as a group. For many of those I spoke to, burying and mourning all the corpses together made sense since, in José's words, 'they died together, [had] been together and [would] remain together in the cemetery, where they should be' ${ }^{30}$ For other relatives like Pablo Trenado, whose grandfather and uncle's bodies were buried in the mass graves, a collective burial meant that they could all be gathered in the same place, especially considering the manner in which some bodies had 'turned out' during the excavation: fractured and worn away. ${ }^{31}$ Their collective reburial involved the design of a hollow structure where individual coffins containing the remains of each unnamed corpse would be stored. Each small casket would then be prepared for examination and given the individual's case number should any relative wish to identify 


\section{Zahira Araguete-Toribio}

the bones of their dead kin in the future - perhaps, as some acknowledged, in the advent of a more advanced technology of reassociation. Their names - found using the death certificates in the archive and corroborated by testimonies - would be carved on the stone that covered the exterior of the monolith (see Figure 1). For some relatives, however, it was difficult to come to terms with the intricacies of the identification process. An excerpt from a conversation with José SánchezPaniagua, his sister Consuelo and Esperanza Muga Blasco (the latter a woman who lost her father, grandfather and uncle in the executions of 1939) elucidates how the idea of these communal internments was negotiated and wrestled with the notion of a positive identification when people imagined the way in which the human remains of their ancestors would be returned after the exhumation:

ZA: What does it mean to you to recover the mortal remains of your relatives?

EM: Well, what I don't know is, how do they know what bones belong to some families and which ones to another? The bones, I mean, it must be because of the bones.

ZA: Yes, after they have been exhumed, it is the archaeologist who studies them and tests them.

EM: But bones, I don't know what evidence must be in bones.

CSP: Did my brother not mention to you how it will be done? Did you not tell her José?

JSP: Yes, yes I told her but she might not remember now ... We will build a common burial site in the cemetery. The bones will come out from the ground where they are. They will take them to Cáceres, where they will be analysed. They will classify them and place them inside small numbered boxes and bring them back to the cemetery. At the cemetery, we will build a mausoleum where they will all be buried together. So you will not receive the mortal remains of your father, grandfather or uncles. They are all going to be together in the mausoleum. You will know your family is there, but for now, you will not know exactly who they are.

EM: [to José and Consuelo] And your grandfather, will he be there too?

JSP: Yes, our grandfather too.

CSP: Your father's bones will be all together because they will know which bones belong to each body. But you will not know which body is your father's because in order to know that you need a DNA test and this costs a great deal of money.

JSP: and time...

CSP: Let's imagine you say tomorrow 'I want to know and I am going to pay to identify my father'. Then they will take them out, because each one is classified in a box, and they will find out. ${ }^{32}$

The difficulties faced in the process of identification altered the expectations of some family members such as Esperanza's, who, on several occasions before and during the exhumation, manifested her hope to fully identify her three relatives buried at the mass grave. During the exhumation campaign, Esperanza was eager to learn which tests archaeologists would perform on the corpses to reveal her relatives' identity and had asked about the possibility of a DNA analysis. Even when we spoke about DNA analysis in our visit she seemed familiar with the term, 
demonstrating the wide reach of this scientific method and its presumed efficacy in many social milieus. DNA analysis was conceived as a successful tool, especially when Consuelo reassured Esperanza how 'they' [scientists] might be able to find out in the future. Indeed, this was not the first time someone manifested a clear familiarity with DNA technology. Many had referred to it at the different exhumations in which I participated, associating the sight of the dead body with its forensic meanings and treatment, and many members of the scientific team attributed this local knowledge of some practices such as DNA testing to their regular presence in mass media (for example in television series such as CSI or news reports). Their observations coincided with the view of some authors like Jacque Lynn Foltyn, who point out the role of the corpse and its forensic handling as the centre of recent mass culture products. ${ }^{33}$ The ascent of the dead body and its scientific meanings as a theme of public interest, Foltyn argues, has also reasserted the authority of DNA evidence and examination more broadly.

Explaining the limitations of these identification methods, especially in difficult contexts such as that of Puebla's mass grave, contested the popular images (involving certitude) generated by these cultural representations of scientific practice. In our last weekend in Puebla, I accompanied Laura Muñoz to visit Esperanza one more time. It was clear by this point that a DNA test was unfeasible considering the extreme deterioration of over half of the skeletons found. Laura explained to Esperanza that an individual identification had to be considered as a 'remote possibility', given that acquiring additional biographical information about the corpses that were in better condition - and thus targeting a DNA analysis - was extremely complex. Moreover, Laura explained that many of the bones needed for a positive DNA extraction, like dentures or femurs, were missing as they had either decayed or been removed by animals. The archaeologist however added that if indicators that associated a corpse to a specific family emerged during her study of the human remains - for instance, they knew Esperanza's father had a limp - then a DNA test might be carried out on that concrete set. Esperanza aspired to recuperate her relatives' remains but also recognised the difficulties that the uncertainty over these men's ante-mortem traits and their executions - as the archaeologist explained had caused on the identification process.

Unresolved identification ultimately determined communal burials, prompting the shared experience of families' bereavement in Puebla as well as elsewhere. These collective burials of individuated human remains were ensnared with the predicaments of time, place and conservation but also with the social politics around the remembrance of the war in Extremadura. The act of re-inhuming these remains together celebrated the individual identities of the defeated as well as their common Republican histories, prompting the formation of an imagined community of mourners around their deaths. ${ }^{34}$ In his seminal study, Benedict Anderson highlights how death is at the core of social forms of collective recognition and entangled with what he terms 'the mystery of [social] re-generation'. ${ }^{35}$ Reburials such as that performed in Puebla de Alcocer aimed to place the dead and their stories back into the national collective imagination. In so doing, the act turned these corpses into symbols of a particular identity shared with other historical 
memory groups. Nonetheless, these sites were also spaces of contestation, where different ideas converged about the type of burial, inscriptions or funeral acts to be performed (such as whether religious, secular, or with political symbols etc.). ${ }^{36}$ Despite disagreements, they produced localised expressions and funerary vestiges, which fixed these men's familial, political and social identities in the public realm of the cemetery.

\section{Return to the cemetery}

Throughout the undertaken fieldwork, most families and activists I met in Extremadura understood the reburial of the human remains in the cemetery as a manner of honouring the defeated. Most activists and family groups involved in the search for the dead often denounced these Republican bodies in mass graves for the loathsome way in which they were buried, emphasising their displaced condition. For many, these 'dead relatives' were still today lying on roadsides and outside of cemeteries 'just like dogs'. José Sánchez-Paniagua, for instance, mentioned on various occasions that people should be interred inside the cemetery as only 'animals' were buried outside. Likewise, other families' indifference towards the deaths or the refusal to recover a relative's body from the mass graves was strongly criticised by some as a careless and irresponsible attitude towards the ancestor. Returning these dead to the cemetery constituted a dislocated act in time to restore their privy legitimacy and humanity but also complied with a certain 'morality of death' - to evoke Heonik Kwon's expression ${ }^{37}$ - based on the belief that these bodies, whether kin, fellow militant or neighbour, had endured a form of 'undignified' death and burial for years. As in the case of the familial rituals and commemoration around those killed and buried in mass graves in Vietnam that Kwon discusses ${ }^{38}$, these internments, including their design and commemorative rituals, aimed to re-signify the negative meanings associated with their violent deaths. Situating these dead bodies inside the realm of the cemetery bestowed the remains a sacred and solemn character.

Francisco Ferrándiz has argued that the exhumation, reburial and commemoration of the Republican dead have often been enmeshed with the distinct 'mortuary rituals' that different historical memory associations entertain. ${ }^{39}$ At a national level, for instance, important groups such as the national Asociación para la Recuperación de la Memoria Histórica (Association for the Recovery of Historical Memory, ARMH henceforth) and Foro por la Memoria (Forum for Memory, Foro henceforth) have differed in their views around exhumation processes. For $\mathrm{ARMH}$, the exhumation and reburial of corpses is directly connected to the wishes of relatives and their forms of mourning. For Foro - a group connected to the Communist Party - these acts constitute a way to vindicate, first and foremost, the victims' political identities and histories. As such, their exhumations and commemorations are often filled with Republican imagery, political speeches, and left-wing songs and hymns. ${ }^{40}$ In Puebla, where the socialist town hall facilitated the exhumation and inhumation of the remains, the reburial was perceived - as the socialist town mayor told me in an interview - as an act that ought to be dominated 


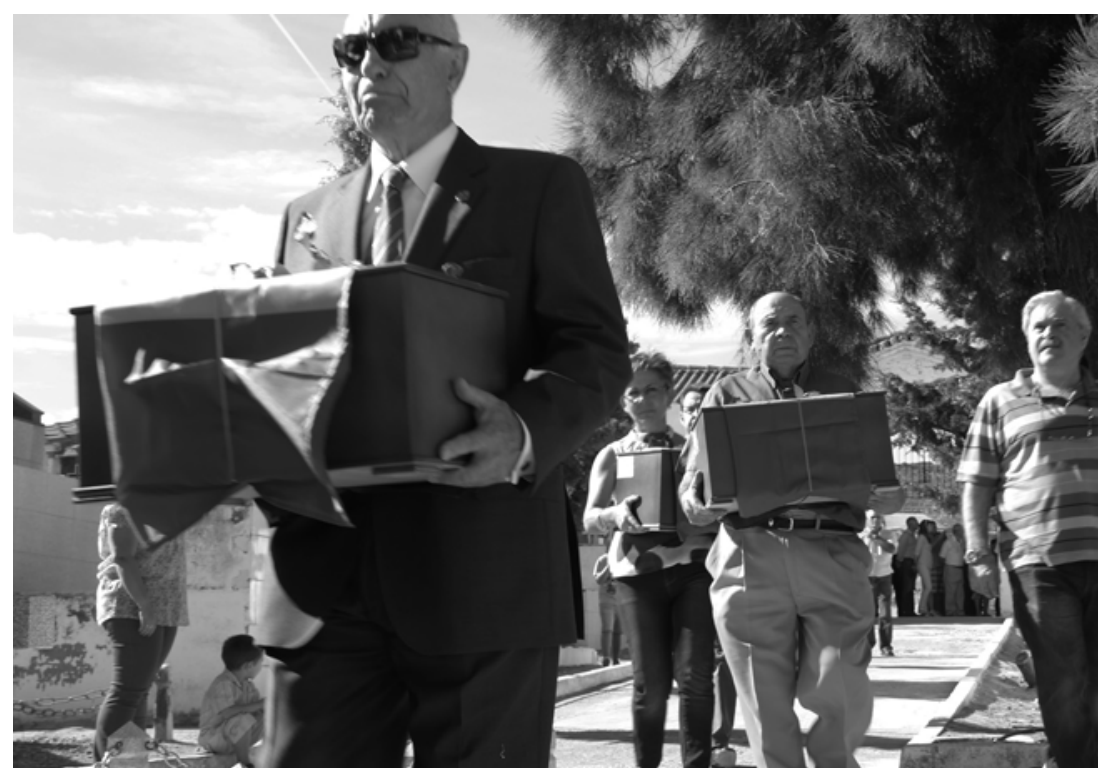

Figure 2 Families of the dead and neighbours from the village carry the coffins to the mausoleum in Puebla de Alcocer (September 2013).

by the wants of the families of those killed and buried in the trenches. ${ }^{41}$ Indeed, throughout the event, relatives and political representatives celebrated the reburial as a collective act of justice and equality. Nonetheless, one could appreciate how the act also foregrounded conflicting individual and collective intentions and different familial and political desires.

In September 2013, relatives, neighbours, local and regional authorities and members of the archaeological team attended the reburial event held in the cemetery of Puebla de Alcocer (Figure 2). The inhumation of the corpses was accompanied by a varied secular liturgy that honoured the deceased and recalled their executions. Before the event, coffins decorated with Republican flags and a red rose were transported by some relatives and the archaeologist from the building in which they had been stored to the autopsy room in the cemetery, ready for their collection during the ceremony. The objects found in the mass grave with the corpses (such as spoons, shoe soles, medals or bullets) were arranged as part of an exhibition at the House of Culture (Casa de la Cultura), where neighbours and families would later gather to learn about the results of the exhumation. The act began with the movement of these coffins from the cemetery's room to the mausoleum. Relatives and some village neighbours emotionally carried the small wooden coffins, personally transporting the dead to their final resting place. Each coffin was placed next to the monolith built for their burial while a cellist played classical pieces to accompany the act. Once the coffins were piled and arranged by 
the monument, relatives, local politicians and members of the research project read texts prepared for the occasion. After participants had spoken, a line of men and women, including the archaeologist Laura Muñoz, passed the small coffins to be deposited on the shelves inside the mausoleum's crypt.

The act of Puebla was marked by the voices, eulogies and gestures that emotively recalled intimate connections to the dead and uttered the political sentiments of the living. Familial words and poems celebrated the moment of the reunion between the remains and their living relative, tracing common genealogies. Consuelo, Josés sister, expressed how the reburial concluded years of waiting for her father, who finally saw the commemoration of his death and the burial of his body. For others like Esperanza's brother, the act enabled him to once again remember his father, grandfather and uncle after years of separation. It meant, as he stated, a new beginning in the history of the family and the village community, as the remains returned to a place, in his words, 'with no ideological distinctions'. Though Republican iconography and attire were limited at the cemetery, the presence of local PSOE representatives and the recollection of fragments from these men's political histories provided the event with deep left-wing meanings. In their speeches, relatives and political leaders emphasised the victims' commitment to the fight against Franco's oppressive regime and for the values of the Second Republic. In a village where the divisions between right- and left-wing neighbours had been profound since the end of the war, the reburial sought, as the PSOE town mayor explained, to 'repair' the village's familial and social fabric. Nevertheless, for many second and, especially, third generations, who had not experienced the war directly, the act was also a platform to express a connection to their ancestors' struggle, reasserting individual left-wing identities and fuelling present ideological positions.

The act of reburial elucidated other contesting views. In How Societies Remember, Paul Connerton analyses the way in which commemorative inscriptions and bodily practices are at the core of social continuity and the transmission of collective memories. ${ }^{42}$ Indeed, the oral, bodily and material expressions during the act spoke of a collective wish for reparation and remembrance, especially as participants called for reconciliation in their texts and on the engravings of the memorial's stone (see Figure 1). Nonetheless, the same manifestations that Connerton identifies as cohesive mechanisms also prompted the unease of relatives who would have preferred other religious rituals. After the reburial at the cemetery and during the afternoon meeting at the village House of Culture (Casa de la Cultura), Luisa Cabanillas Bayón, a relative of two of the men in the mass grave, asked José and the town mayor why the ceremony had not been officiated by a priest. Luisa explained that she would have liked to bid farewell to her kin's remains with a religious ceremony - just like in other village ceremonies to the dead. The wishes of Luisa, of Catholic faith, indeed collided with those of other relatives and members of younger generations, for whom a civil ceremony was a more suited way to bury the Republican dead.

The experience of the collective reburial of the human remains in Puebla de Alcocer elucidated the heterogeneous character of the communities formed around the exhumation. Time most certainly conditioned the reburial choices of 
some third generation relatives who sought the rapid inhumation of their ancestors' remains before older relatives passed away. The futility of a positive identification and a DNA match, resulting from the scientific interpretation the mass grave, superseded individual wishes like those of Esperanza to recover and bury her father and uncles' remains in a family tomb. The state of the bones' degeneration during the exhumation had impeded their individuation eliciting a reburial that resembled those enacted before DNA testing was carried out on the corpses found in the mass graves from the civil war. In Puebla, the reburial act elicited collective expressions, which assembled familial and political portraits of the dead, reattaching these remains to particular stories and providing them with human and social traits. Individual imaginings of the dead retraced the identity of these unnamed bodies revealing intimate experiences of enduring violence across generations as well as the familial and political aspirations of living relatives. In the project, individual desires were often at odds with group decisions, exemplifying the complexities at stake in making collective commemorative practices.

\section{Conclusions}

In Spain, the predicaments faced during exhumation processes have made the inhumation and commemoration of human remains a context specific activity, linked to the social, scientific and political particularities of each case. Over the years, family burials have coexisted with collective interments, elucidating the myriad approaches to reburying the Republican dead and the decentralised character of their commemoration. The scarce involvement and commitment of the central government in the organisation and endorsement of these acts has turned them into independent civil society endeavours in localised scenarios. As opposed to state-driven forms of commemoration - for instance, those documented after World War One - where rituals and performances reclaimed national identity from the top down, the reburial acts discussed in this article reflect the way in which the commemoration of the civil war dead is negotiated between families, scientists and political members in their communities.

Far from happening in isolation, however, these reburial acts are informed by an emerging aesthetics of commemoration - marked by the enactments and physical constructions that emerge from shared reburial experiences around the country. These practices constitute a 'bottom-up reparation model' of commemoration in which the central Government has become a mere facilitator. ${ }^{43}$ Such collective acts are critical reminders of the Spanish Government's long-eluded responsibility for redress. They are also, however, examples that remind us of the important role grassroot demands and desires can play in official commemorations and reparation programmes. At a time when state-led programmes and international transitional justice models have also received strong criticisms elsewhere - for what some consider as lacking in engagement with local scenarios, practices, and priorities $^{44}$ - these localised commemorations can be valued for the manner in which they encompass the particular interests of families, associations and local political actors. Fraught with disparate views, these commemorations also elucidate the 


\section{Zahira Araguete-Toribio}

ways in which social disagreements and collective action are negotiated in intimate yet translocal contexts.

\section{Acknowledgements}

I thank the Project for the Recovery of Historical Memory of Extremadura (PREMHEx) and especially Laura Muñoz Encinar for the constant insights and collaboration in this research. I am deeply grateful to the families from the Agrupación de Familiares de Puebla de Alcocer for allowing me to take part in the exhumation and reburial process and for sharing their experience with me, and I likewise acknowledge the financial support for this research from the European Research Council received as part of the project 'Bosnian Bones, Spanish Ghosts' with Dr Sari Wastell as the Principle Investigator (grant no. 241231).

\section{Notes}

1 See S. E. Wagner, 'The Making and Unmaking of an Unknown Soldier', Studies of Social Science 43:5 (2013), 631-56.

2 T. W. Laqueur, 'Memory and Naming in the Great War', in J. R. Gillis (ed.), Commemorations: The Politics of National Identity (New Jersey, Princeton University Press, 1994), pp. 150-67; J. R. Gillis, 'Memory and Identity: The History of a Relationship', in J. R. Gillis (ed.), Commemorations: The Politics of National Identity (New Jersey, Princeton University Press, 1994), pp. 3-25; J. Winter, Sites of Memory, Sites of Mourning, (Cambridge, Cambridge University Press, 1995).

3 S. E. Wagner, To Know Where He Lies: DNA Technology and the Search for Srebrenica's Missing (Berkeley/London, University of California Press, 2008);

S. Wagner, 'The Social Complexities of Commingled Remains', in B. Adams \& J. Byrd (eds), Commingled Human Remains: Methods in Recovery, Analysis and Identification (New York, Academic Press, 2014); Wagner, 'The Making and Unmaking of an Unknown Soldier'.

4 M. Weiss, 'The Body of the Nation: Terrorism and the Embodiment of Nationalism in Contemporary Israel', Anthropological Quarterly, 75:1 (2002), 37-62; Wagner, To Know Where He Lies.

$5 \mathrm{H}$. Kwon, After the Massacre: Commemoration and Consolation in Ha My and My Lai (Berkeley/London, University of California Press, 2006); H. Kwon, Ghosts of War in Vietnam (Cambridge, Cambridge University Press, 2008).

6 Kwon, After the Massacre; Kwon, Ghosts of War; A. Klima, The Funeral Casino: Meditation, Massacre and the Exchange with the Dead in Thailand (Princeton, Princeton University Press, 2002); V. Schwarcz, 'Strangers No More: Personal Memory in Interstices of Public Commemoration', in R. Watson (ed.), Memory, History and Opposition Under State Socialism (Santa Fe, School of American Research Press, 1994).

7 M. Petrović-Šteger, 'Mobile Sepulchre and Interactive Formats of Memorialisation: On Funeral and Mourning Practices in Digital Art', Journeys 13:2 (2012), 71-89. 
8 S. Jasanoff, States of Knowledge: The Co-production of Science and the Social Order (London, Routledge, 2004).

9 Wagner, To Know Where He Lies; Wagner, 'The Social Complexities'.

10 Wagner, To Know Where He Lies, p. 255.

11 Ibid.

12 In Spanish, Ley de Memoria Histórica, or in its full legal definition: Ley 52/2007, de 26 de diciembre, por la que se reconocen todos los derechos y se establecen medidas en favor de quienes padecieron persecución o violencia durante la guerra civil y dictadura (Law 52/2007, from 26 December, that recognises all rights and establishes measures in favour of those who experienced persecution or violence during the Civil War and dictatorship).

13 F. Ferrándiz, 'Exhuming the Defeated: Civil War Mass Graves in 21st Century Spain', American Ethnologist, 40:1 (2013), 38-54.

14 URL: http://leymemoria.mjusticia.gob.es/cs/Satellite/LeyMemoria/es/inicio (accessed 8 April 2015).

15 F. Ferrándiz, 'Autopsia Social de un Subtierro', Isegoría: Revista de Filosofía moral y Politica, 45 (2011), 525-44, 541.

16 Ibid.

17 L. Rios, J. I. Cardoso \& J. Puente Prieto, 'Identification Process in the Mass Graves from the Spanish Civil War', Forensic Science International, 199 (2010), E27-E36.

18 Ibid., E27.

19 Ibid.

20 Personal communication with Berta Silva.

21 This was conducted by scientists from Aranzadi at the Universidad Autónoma de Madrid and with the support of the National Association for the Recovery of Historical Memory.

22 URL: http://exhumacionvaldenoceda.wordpress.com (accessed 16 April 2015).

23 Excerpt from the 'Exhumation Practice Protocol', Boletín Oficial del Estado (Madrid, Ministry of the Presidency, 2011), pp. 101917.

24 Ferrándiz, 'Autopsia Social'; J. Montero, 'Exhumando el Legado Material de la Represión Franquista: De la Percepción Social a la Encrucijada Jurídica y Patrimonial', in J. Almansa Sánchez (ed.), Recorriendo la Memoria (Oxford, Archaeopress, 2010); As Juan Montero has further argued, many of these protocols have failed to engage with a treatment and definition of mass graves that relates to the vision shared by the scientific teams and associations that work on them. See 'Exhumando el Legado'. Many of these protocols describe mass graves as archaeological sites, on some occasions regulated by regional laws of patrimony. This is critiqued by some archaeologists who deem that the treatment of mass graves as archaeological sites under patrimony laws entails their excavation with the same protocol as, for instance, pre-historic sites. Others believe that these laws are instead needed to regulate exhumation practices. Further, still, there are archaeologists who do not provide any definition that addresses the particular requirements of the Civil War exhumations.

25 Ferrándiz, 'Exhuming the Defeated'.

26 In regions such as Extremadura, the example discussed here later, mortal remains 


\section{Zahira Araguete-Toribio}

are returned to families or the associations that promote the exhumation and reburial. As an activity regulated by the Law of Patrimony in the region, however, the outcomes of these exhumations are also overseen by the administration. Contrary to what is advised in the national protocol, bodies in the region are usually buried without their belongings. Following the article 53(e) of the Law of Patrimony, and as a measure to secure their protection, objects should be kept at the 'pertinent provincial museum', or regional museum, in the absence of direct relatives that can recover them.

27 Wagner, 'The Social Complexities'.

28 Not all regions have an institutional agreement for the historical study and exhumation of mass graves (see the case of Castilla y León addressed by Ferrándiz [2013], among others). In Extremadura, the university project supported by regional and provincial administrations has been running since 2003.

29 Interview with José Sánchez-Paniagua, Puebla de Alcocer, 11 June 2012.

30 Ibid.

31 Interview with Pablo Trenado, Puebla de Alcocer, 14 August 2012.

32 Interview with Esperanza Muga Blasco, José Sánchez-Paniagua, and Cosuelo Sánchez-Paniagua Puebla de Alcocer, 11 June 2012.

33 L. J. Foltyn, 'Dead Famous and Dead Sexy: Popular Culture, Forensics, and the Rise of the Corpse', Mortality, 13:2 (2008), 153-73.

34 B. Anderson, Imagined Communities (New York, Verso, 1983).

35 Ibid., p. 11.

36 Ferrándiz, 'Exhuming the Defeated'.

37 Kwon, After the Massacre.

38 Kwon, After the Massacre; Kwon, Ghosts of War.

39 F. Ferrándiz, 'The Return of Civil War Ghosts: The Ethnography of Exhumations in Contemporary Spain', Anthropology Today, 22 (3), 7-12.

40 Ibid., 9.

41 Interview with Manuel Moreno Delgado, Puebla de Alcocer, 11 June 2012.

42 P. Connerton, How Societies Remember (Cambridge, Cambridge University Press, 1989), p. 72.

43 Ferrándiz, 'Exhuming the Defeated'.

44 R. Shaw \& L. Waldorf, Localizing Transitional Justice: Interventions and Priorities After Mass Violence (Stanford, Stanford University Press, 2010). 